\title{
Performance Analysis of Sea Water Solar Still To Produce Fresh Water and Salt Using Flat Plate Collectors
}

\author{
Mulyanef * , Duskiardi, and Rahmad Hidayat \\ Department of Mechanical Engineering, University of Bung Hatta, 25243 Padang, Indonesia
}

\begin{abstract}
Fresh Water and salt are the most important necessities in human life. The scarcity and the difficulty to get fresh water and salt became main problems that emerge in many places such as for people who live in coastal areas and small islands where their main source of water and salt is the sea water. In order to obtain fresh water, people needs to process seawater into fresh water and salt. The term of fresh water used here means water which is free from dirt, bacteria, and other substances that are harmful for human health. To process the sea water into fresh water and salt has been done by distillation technic. The distillation technic requires heat to evaporate seawater before condensed and produce clean water. Heat for distillation process can be derived from a variety of sources, one of them is solar energy. The purpose of this study is to compare between a flat plate with one slope cover and two slope cover to produce fresh water and salt. The distilled water was tested in laboratory to determine whether the quality of water and salt after distillation meets the consumable requirements. The working principle of the distillator is by filled the basin with sea water and then heated with solar power. The water will be evaporated and due to the different of temperature between inside and out side of cover so that the condensation accurs at inside of cover. The condensed water will flow through surface of glass cover and then the distilled freshwater gathered in storage. The process will continue until water runs out and creates salt crystals in the basin. Solar distillation testing by using one slope cover with a size of $140 \mathrm{~cm}$ x $220 \mathrm{~cm}$ produce $3,482 \mathrm{ml} /$ day of clean water and 322 grams of salt / 4 days at average intensity of $697 \mathrm{~W} / \mathrm{m}^{2}$. While solar distillation by using two-slope cover with size of $80 \mathrm{~cm} \times 50 \mathrm{~cm}$ produce $1,551 \mathrm{ml}$ clean water/day and 199.9 grams of salt / 4 days.
\end{abstract}

\section{Introduction}

Solar energy is safe, free, and pollution-free renewable energy (without $\mathrm{CO}_{2}$ emissions). Opportunities to utilize solar energy in Indonesia, as renewable energy is increasingly to be considered in Indonesia, where geographically is a tropical country and solar energy is emitted during the year. Indonesia also has the most extensive coastal area that supports to

* Corresponding author: mulyanef@bunghatta.ac.id 
process of transforming sea water into fresh water and salt-making business, both in small scale and industrial scale. The process of seawater into freshwater is known as desalination process [3]. Desalination is a separation process used to reduce dissolved salt content of brine to certain level so that water can be used. The whole process of desalination requires energy to separate salt from seawater. If desalination is conducted by conventional technology, it would require the burning of large quantities of fossil fuels (clean water production of $1,000 \mathrm{~m} 3$ / day requires 10,000 tons of oil per year), while the availability of this fuel is decreasing. So, other sources of energy are needed such as the purification of sea water using solar energy [7]. Solar energy is a promising solution to reduce cost. Indonesia as an archipelagic country with coastline reaching $81,000 \mathrm{~km}$ and has high potential to produce large quantities of salt. Although Indonesia is a maritime country, efforts to increase salt production have not been in demand. The necessity of salt in Indonesia increase from year to year, along with population growth and industrial development. One way to process sea water into fresh water and salt is distillation. Distillation requires heat to evaporate seawater before it is condensed so that it can produce clean water.

There are several studies that have been done to treat sea water into freshwater and salt using solar distillation test among others, conducted by; the authors [2] conducted "Experimental study of the enhancement parameters on a single slope of solar still productivity". The productivity of solar still increased by $51 \%$ when combined with enhancers such as asphalt basin liner and sprinkler in which has been applied to the still. The condition and temperature of solar still environment also has direct effect on the productivity of distilled water. The productivity of evening distilled water accounts for $16 \%$ of daily output. This study also showed that solar daily productivity can still be increased by reducing the water depth in the basin; the authors [5] conducted a study on "the Effect of water depth on productivity of solar still with thermal energy storage". The experiment shows that by decreasing the water depth in the basin, it will increase the productivity of diesel still; the authors [1] conducted a research on "Desalination of water using conventional basin type of solar still ". Field experiment was conducted from June 7, 2011 to June 09,2012 . He found that average distilled water production is $1.80 \mathrm{lit} / \mathrm{m} 2$ per day and average production is $0.20 \mathrm{lit} / \mathrm{m} 2$ per hour. While the maximum-daily distilled water production obtained $3.76 \mathrm{lit} / \mathrm{m} 2$ and the production of the maximum distilled water is 0.46 lit / m2 per hour; the authors [4] examined "the Development and performance analysis of a domestic". The tests were conducted from June, July, August, September, October, November, and December 2011. The highest solar still productivity occurs at June $(5738 \mathrm{ml})$ and the lowest productivity occurs at December $(1,510 \mathrm{ml})$, due to the solar intensity in June is the highest compared with the other months. The average productivity of diesel still from June to December is $3,000 \mathrm{ml}$ and the overall efficiency is $22 \%$; the authors [6] has conducted experiments on "Performance study of sea water distillation by solar energy to generate salt and fresh water"; The results showed that solar collectors using reflectors generate higher productivity compared to not using reflectors. The volume of seawater in each basin is $6,000 \mathrm{ml}$ and the collector area of $80 \mathrm{~cm} \times 50 \mathrm{~cm}$ can produce condensate or fresh water of $1,551 \mathrm{ml}$ per day and salt of 199.9 grams for 3 (three) days of testing.

\section{Experimental Setup}

Experimental equipment used in the research of solar still namely; Basin liner, glass cover, insulating material, distillation channel, and measuring instrument. 


\subsection{Basin Liner}

Basin liner is a major part of solar still, which serves to absorb solar radiation transmitted through a transparent glass cover. Basin Liner must be resistant to hot salt water, has high absorption of solar radiation, strong and easy maintenance. In order to increase the absorptivity of solar still, Basin liner layer is painted black, not to mention that in this research we used aluminum plate.

\subsection{Glass Cover}

In this study, we use glass cover with a thickness of $4 \mathrm{~mm}$ and glass average transmissivity value of 0.89 , angle of 35 degrees as shown in figure 1 . To reduce heat loss, silicone rubber is installed on the edge of the glass frame cover.

\subsection{Insulating Material}

Insulating material serves to reduce the heat lost from the bottom and side of the solar still wall. Insulating material used in the solar still is glass wool with a thickness of $5 \mathrm{~cm}$ and thermal conductivity of $0.045 \mathrm{~W} / \mathrm{m}^{2}{ }^{\circ} \mathrm{C}$.

\subsection{The Distillate Chanel}

The distillate line used to collect condensate from the bottom edge of glass cover and carry it to storage compartment. It is made from aluminum sheets, and the side wall is made from wood as thick as $16 \mathrm{~mm}$.

\subsection{Measuring Device}

\subsubsection{Temperature}

Temperature variations in various solar still locations are measured by thermocouple (k-type) merged into data logger. The accuracy of this device is in the range of $0.3{ }^{\circ} \mathrm{C}$ for temperature measurements 1 and $99{ }^{0} \mathrm{C}$. There are five thermocouple points used to measure temperatures in solar still, namely; ambient temperature, absorbent plate temperature, water temperature in basin, evaporation temperature, and glass temperature.

\subsubsection{Solar Radiation}

In the present study a solarimeter is used to measure the solar radiation. This device measures the instantaneous intensity of radiation [its range from 0 to $1,2 \mathrm{~kW} / \mathrm{m}^{2}$ ].

\section{Work Principle of Solar Still}

Solar radiation enters the collector through transparent glass cover to absorbent plate. On the absorber plate, solar radiation is converted into heat. Seawater in the basin will become hot, and the water evaporates because its density is lower than salt and water vapor rises upward at the inside of glass cover. Because there is a temperature difference between inside the basin and the solar still environment, condensation occurs at the inside of glass cover. The condensation result attached to the inside of glass cover flows downward following the slope of the cover glass. Condensation results are held and this is called fresh water productivity. To produce salt, sea water is warmed continuously from morning to evening every day until it evaporates completely and will form salt crystals. Fig. 1 show schematic diagram of the solar still producing fresh water and salt. 


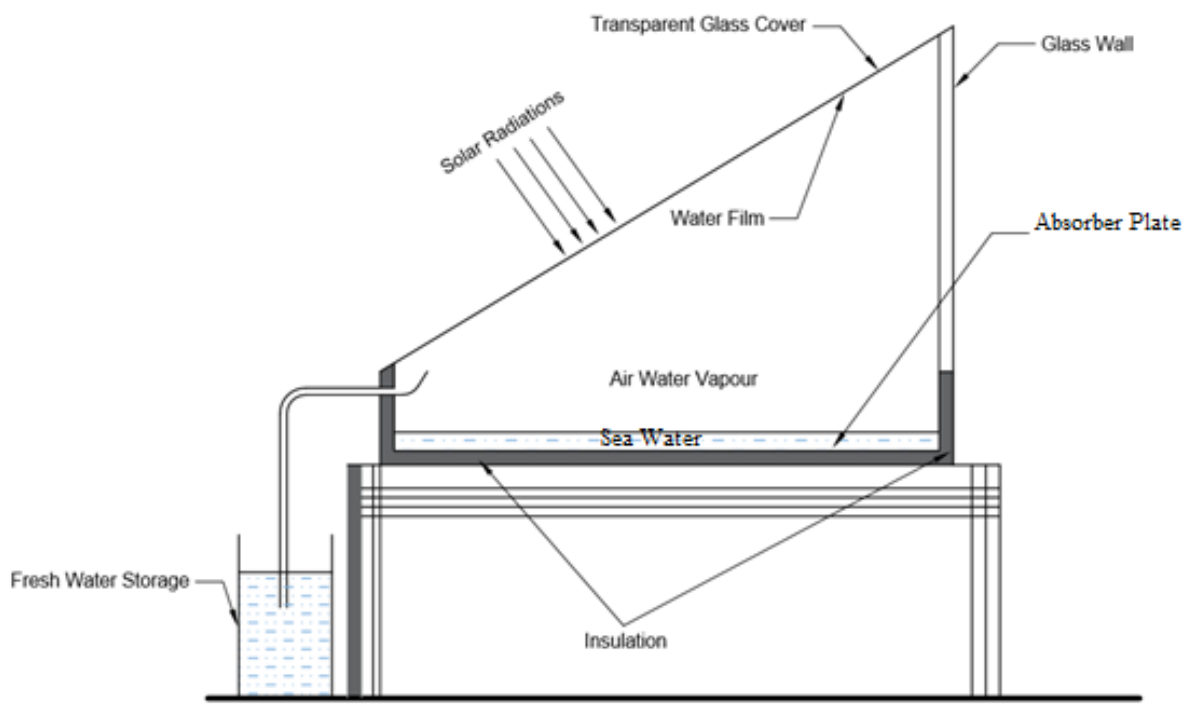

Fig. 1. Schematic diagram of the solar still to produce fresh water and salt

\section{Result and Discussions}

This section presents the effect of different conditions on solar still productivity, such as ambient temperature, different water depths, different basin coating materials (eg black paint, aphalt), sprinklers (cooling film) on glass and wind speed. Different variables are measured per hour such as glass temperature (Tg), ambient temperature (Ta), sea water temperature $(\mathrm{Tw})$, absorbent plate temperature $(\mathrm{Tp})$, vapor temperature $(\mathrm{Tsv})$, solar Radiation (I), wind velocity ( $\mathrm{Vw}$ ), Condensate productivity (Ma) and salt productivity (Mg). Fig. 2 shows variations in various solar still temperatures on 15/3/2017.

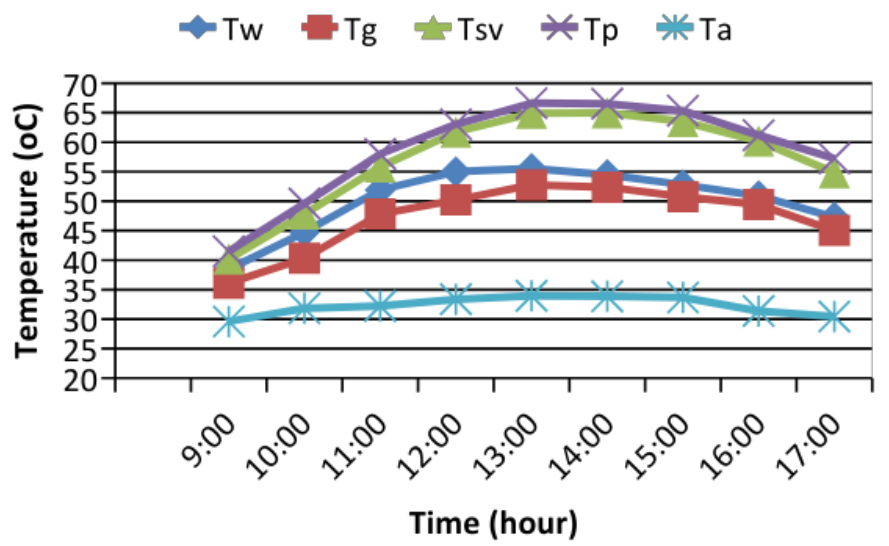

Fig. 2. Different temperature variations on solar still 
It can be seen that the initial temperature (09:00) is still low and rises steadily until 12:00. After 12:00 the temperature at the collector begins to fall again, this is caused by the solar radiation that goes into the collector. The maximum temperature on basin obtained on 13.00. At the time, the evaporation temperature is $65{ }^{\circ} \mathrm{C}$, water temperature $55^{\circ} \mathrm{C}$ and the ambient temperature obtained $36{ }^{\circ} \mathrm{C}$. The higher solar intensity would increase the temperature in the environmental temperature collector significantly. The highest temperature is generated by an absorbent plate and followed by evaporation temperature, water temperature in basin, glass temperature and ambient temperature.
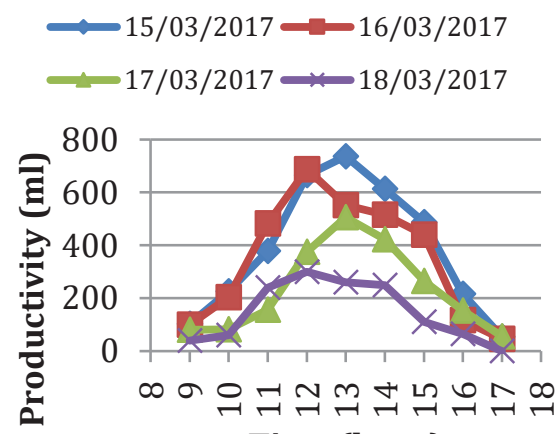

Time (hour)

Fig. 3. The relationship between condensate productivity for 4 days of testing and $12,000 \mathrm{ml}$ of water in basin.
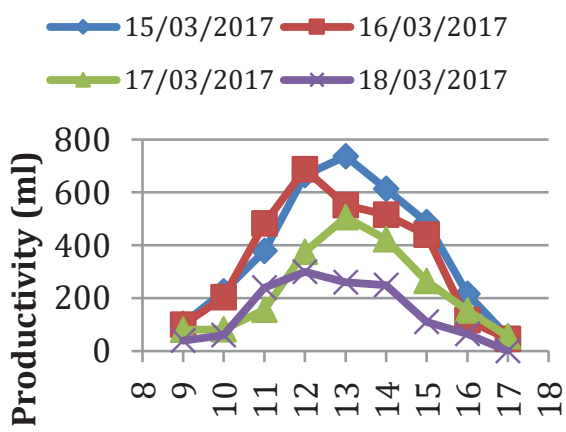

Time (hour)

Fig.4. The relationship between condensate productivity for 4 days of testing and $6,000 \mathrm{ml}$ of water in basin

Fig. 3 and Fig. 4 shows the productivity of fresh water condensation for sea water volume in $12,000 \mathrm{ml}$ basin and $6,000 \mathrm{ml}$ in basin. Fresh water productivity in the first day of testing was higher than its productivity on the second, third and fourth test day. This is because during the first test day, the sea water in the basin was still high and the salt content was low. While on the second day, condensate productivity began to decline and the salt content in the basin was higher.

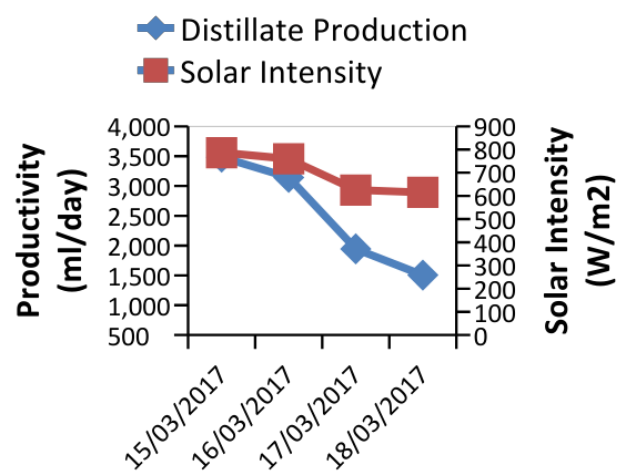

Fig. 5. The relationship between fresh water productivity and solar intensity in the first test with $12,000 \mathrm{ml}$ of water in basin.

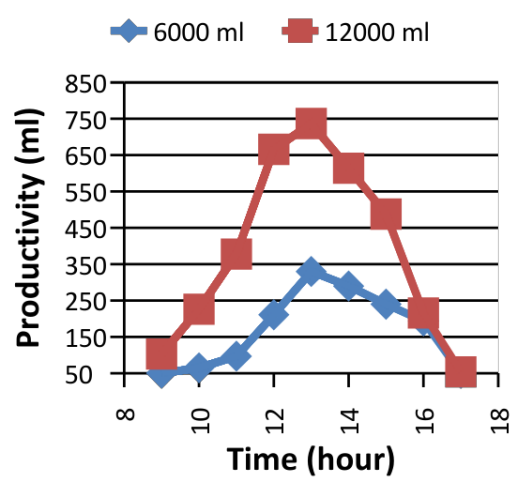

Fig. 6. Relationship of fresh water productivity with time and different size of solar still 
Fig. 5 displays the relationship between fresh water productivity and solar intensity on the first test with $12,000 \mathrm{ml}$ of water in basin. Fresh water productivity is closely related to solar intensity. The higher the solar intensity, the higher the productivity of fresh water. The highest productivity was obtained on the first day of testing (March 15, 2017) with 3,482 $\mathrm{ml}$ of fresh water and the lowest on the fourth day of the test with $1,505 \mathrm{ml}$ and the average solar intensity during the test of $787 \mathrm{~W} / \mathrm{m}^{2}$.

Fig. 6 Displays the relationship between freshwater productivity and time. High productivity for both sizes of solar still is produced at 13.00, compared to 09.00-12.00 and 14.00-17.00. This is because solar intensity in the morning is still low. As the time goes by, the intensity is getting higher until 12:00 to 13:00, solar intensity drop back. The diagram also showed us that for solar still with $12,000 \mathrm{ml}$ of water in basin, it produces more fresh water compared to $6,000 \mathrm{ml}$ of water.

Table 1. Fresh water and salt productivity from solar still

\begin{tabular}{|c|c|c|}
\hline \multirow{2}{*}{ Productivity } & \multicolumn{2}{|c|}{ Volume of sea water in basin } \\
\cline { 2 - 3 } & $\mathbf{6 , 0 0 0} \mathbf{~ m l}$ & $\mathbf{1 2 , 0 0 0} \mathbf{~ m l}$ \\
\hline Fresh Water $(\mathrm{ml})$ & 3,815 & 10,076 \\
\hline Salt $(\mathrm{gr})$ & 199.9 & 322.0 \\
\hline
\end{tabular}

Table 1 displays fresh water and salt productivity for $6,000 \mathrm{ml}$ of sea water in basin. It produced fresh water of 3,815 ml and salt of 199.9 grams. As for 12,000 ml of sea water in basin, it produced $10,076 \mathrm{ml}$ of fresh water and 322 grams of salt. The more of seawater heated in the basin, the more freshwater and salt will be produced. On the contradictory, the more seawater in the basin, the longer time needed to produce salt and fresh water. In this test, it takes four days to obtain salt with average solar intensity of $697 \mathrm{~W} / \mathrm{m}^{2}$.

\section{Conclusions}

- Total productivity for flat plate collector with area of $140 \mathrm{~cm}$ x $220 \mathrm{~cm}$ and $12,000 \mathrm{ml}$ of sea water in basin is $10,076 \mathrm{ml}$ of fresh water and 322 gram of salt. As for collectors with area of $50 \times 80 \mathrm{~cm}$ and $6,000 \mathrm{ml}$ of sea water yields 3,815 $\mathrm{ml}$ of fresh water and 199.9 grams of salt. The average solar intensity during the test is $697 \mathrm{~W} / \mathrm{m}^{2}$ and the time required to produce salt is four days.

- The productivity of solar still is influenced by solar intensity, environmental temperature, wind speed, and water depth in the basin.

\section{References}

[1] Al Faruq, S.M Abdullah. Akter, Md Shaheen. Alamin Md, Islam, Md Zohrul. Global J. Vol.13 Issue 3 Ver. 1.0 (2013)

[2] Badran O.O. Desalination. J. 209 (2007)

[3] Deng, Runya. Xie, Lixin. Lin, Hu. Liu, Jie. Han, Wei.. Energy. J. 36 (2010)

[4] Iqbal, I. Ahmad, A. ARPN J. Vol. 9, No. 7 (2014)

[5] Kumar T R ,Sathish. Bharathi B, Raja. IJSR. J, Volume 2 Issue 3 (2013)

[6] Mulyanef. Duskiardi. Kaidir, Ikhsan, M. Engineering Science and Technology International Conference 3rd..Proc., 153 (2016).

[7] Yilmaz, Ibrahim, Halim, Soylemez, Mehmet, Sait. Desalination J. 291 (2012). 